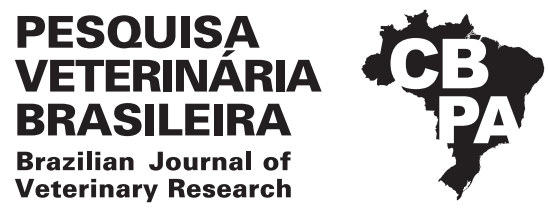

Pesq. Vet. Bras. 39(8):614-621, August 2019 DOI: 10.1590/1678-5150-PVB-5883

Original Article

ISSN 0100-736X (Print)

ISSN 1678-5150 (Online)

\title{
Protocols for preparation of platelet rich plasma (PRP) in Quarter Horses ${ }^{1}$
}

\author{
Stephania Miranda ${ }^{2}$, Maria Fernanda Mello $\operatorname{Costa}^{3,4 *}$ (D), Natália Rebouças ${ }^{2,5}$, \\ Márcia T. Ramos ${ }^{4,6}$, Daniel A.B. Lessa ${ }^{2}$ and Nayro X. Alencar ${ }^{2}$
}

\begin{abstract}
Miranda S., Mello Costa M.F., Rebouças N., Ramos M.T., Lessa D.A.B. \& Alencar N.X. 2019. Protocols for preparation of platelet rich plasma (PRP) in Quarter Horses. Pesquisa Veterinária Brasileira 39(8):614-621. Departamento de Patologia e Clínica Veterinária, Faculdade de Veterinária, Universidade Federal Fluminense, Rua Vital Brazil Filho 64, Niterói, RJ 24230-340, Brazil. E-mail: mfveterinaria@hotmail.com

This study compared two protocols for preparation of platelet rich plasma (PRP) and evaluated the association between manual and automated methods for platelet count using a prospective study design. Eight clinically healthy Quarter Horses had venous blood samples collected at rest. After collection, blood samples were centrifuged twice, using two different protocols including a period of sample resting, either at the start or at the end of the protocol. Platelet counting at the start of the protocol, during, and after obtaining PRP was conducted manually or with an automated counter, followed by comparison of the two methods. In order to investigate platelet degranulation during the protocol, vascular endothelial growth factor (VEGF) was measured at each preparation stage. The protocol with sample resting before centrifugation yielded a more concentrated PRP, and the study verified that both manual and automated methods are comparable and can be used interchangeably for platelet counting. VEGF concentration did not differ significantly between protocols, or among protocol stages. The results indicate that choice of protocol for PRP preparation will affect the quantity of platelets in the final product, although platelet degranulation was not observed as evidenced by the stable VEGF concentrations measured. A larger yield of non-degranulated platelets in PRP is desirable since more $\alpha$-granules will be present, therefore Protocol II is recommended. Both manual and automated counts reliably allow clinicians to obtain platelet counts and the choice of utilizing a manual or automated method is unlikely to interfere with evaluation of the final PRP product.
\end{abstract}

INDEX TERMS: Platelet rich plasma, PRP, Quarter Horses, biotechnology, blood, equidae, investigative techniques, biological factors, horses.

RESUMO.- [Protocolos para o preparo de plasma rico em plaquetas (PRP) em cavalos Quarto de Milha.] Este estudo comparou dois protocolos de preparo de plasma rico em

\footnotetext{
${ }^{1}$ Received on April 3, 2019.

Accepted for publication on April 16, 2019.

${ }^{2}$ Departamento de Patologia e Clínica Veterinária, Faculdade de Veterinária, Universidade Federal Fluminense (UFF), Rua Vital Brazil Filho 64, Niterói, RJ 24230-340, Brazil.

${ }^{3}$ Waikato Institute of Technology (Wintec), Tristram Street, Whitiora, Hamilton 3200, New Zealand.

${ }^{4}$ Faculdade de Medicina Veterinária, Universidade Severino Sombra, Av. Expedicionário Oswaldo de Almeida Ramos 280, Centro, Vassouras, RJ 27700-000, Brazil. *Corresponding author: mfveterinaria@hotmail.com

${ }^{5}$ Faculdade de Medicina Veterinária, Universidade Castelo Branco, Avenida Brasil 9727, Penha, Rio de Janeiro, RJ 21030-000, Brazil.

${ }^{6}$ Universidade Federal Rural do Rio de Janeiro (UFRRJ), Rodovia BR-465 Km 7, Zona Rural, Seropédica, RJ 23890-000, Brazil.
}

plaquetas (PRP) e avaliou a associação entre dois métodos de contagem plaquetária - um manual e o outro automático através de um estudo prospectivo. Sangue venoso de oito equinos da raça Quarto de Milha foi coletado e em seguida foi centrifugado duas vezes utilizando-se dois protocolos distintos: um com descanso antes da primeira centrifugação e outro após a segunda centrifugação. A contagem plaquetária ao início, no meio e ao final dos protocolos foi realizada manualmente e pelo método automatizado, seguida de comparação entre os dois métodos. Para investigar a degranulação plaquetária ocorrida durante o preparo do PRP, o fator de crescimento vascular endotelial (VEGF) foi mensurado em cada estágio dos protocolos. 0 método utilizando o descanso da amostra antes da primeira centrifugação proporcionou a obtenção de um PRP mais concentrado, além de o estudo verificar que ambos os métodos de contagem plaquetária (manual e automatizado) 
são comparáveis e podem ser usados indiferentemente. A concentração de VEGF não foi significativamente diferente entre os estágios de preparo do PRP. Os resultados indicam que o método de preparo afeta a quantidade de plaquetas obtidas no PRP, apesar da degranulação plaquetária não ter sido observada, como evidenciado pela concentração estável de VEGF. Uma maior concentração de plaquetas no PRP é desejável, pois indica que um maior número de $\alpha$-grânulos estará presente na amostra, portanto, conclui-se que o Protocolo II é mais recomendável. Tanto o método manual, quanto o automatizado, pode ser usado de maneira confiável para a contagem plaquetária, não interferindo com a avaliação do produto final (PRP).

TERMOS DE INDEXAÇÃO: plasma rico em plaquetas, PRP, cavalos Quarto de Milha, biotecnologia, equídeos, fatores biológicos, sangue, técnicas de investigação.

\section{INTRODUCTION}

Platelets are produced in the bone marrow from cytoplasmic fragments from megakaryocytes and have essential functions in healing, reepithelization, and conservation of vascular integrity through interactions with endothelial cells (Comar et al. 2009). Numerous growth factors (GFs) are stored inside $\alpha$-granules in the platelets, and once released will act on regulatory processes, including tissue regeneration, chemotaxis, cell proliferation, angiogenesis, immunological regulation and modulation of inflammatory processes (Anitua et al. 2004).

Platelet rich plasma (PRP) is an autologous biological preparation with regenerative properties conferred by the large concentration of platelets and GFs it contains (Andrade et al. 2016), including vascular endothelial growth factor (VEGF), which is the most important angiogenic growth factor, but also promotes vascular permeability and chemotaxis of cells during inflammation (Ng et al. 2006). PRP was first described in the 1970s, although the biological functions of GFs contained in PRP were only investigated later (Ross et al. 1986). More recently, interest in PRP as a therapeutic agent for the treatment of orthopedic (Carmona Ramírez \& Prades 2006, Bosch et al. 2010, Brossi et al. 2015) and skin conditions has increased (DeRossi et al. 2009, Maciel et al. 2012).

Recent reviews on the effects of PRP application in different fields of veterinary (Marcazzan et al. 2018, Tambella et al. 2018) and human medicine (Sheth et al. 2012, Laudy et al. 2015, Bos-Mikich et al. 2018) and although opinions vary as far as the possible applications of PRP in regenerative medicine most critics agree that lack of standardization of protocols for preparation of PRP is negatively impacting on the advance of the use of this bioproduct (Chahla et al. 2017).

Various techniques for equine PRP preparation have been suggested (DeRossi et al. 2009, Vendruscolo et al. 2012) but there is no consensus regarding the gold standard protocol. Differences in centrifugation time, speed, and resting of the sample could potentially influence the concentration of platelets and GFs in the final product, which likely influences the effects of PRP itself (Da Fontoura Pereira et al. 2013). Table 1 summarizes information available in the current literature concerning GFs, while Table 2 summarizes published protocols for harvesting PRP.

The goal of PRP preparation protocol should be to obtain a small volume of plasma with extremely high concentrations of platelets and GFs and minimal concentrations of erythrocytes and leukocytes when compared to the original blood sample (Vendramin et al. 2006, Da Fontoura Pereira et al. 2013).

Table 1. Summary of the current literature regarding source and function of growth factors

\begin{tabular}{|c|c|c|c|}
\hline Growth factor & Source & Function & References \\
\hline TGF-b & $\begin{array}{l}\text { Platelets, neutrophils, } \\
\text { macrophages, } \\
\text { monocytes, natural cell } \\
\text { killers, Th1 cells, bone } \\
\text { extracellular matrix and } \\
\text { cartilaginous matrix }\end{array}$ & $\begin{array}{l}\text { Regulates the mitogenic effect of other growth factors, } \\
\text { stimulates the proliferation of undifferentiated mesenchymal } \\
\text { cells, fibroblast and osteoblast mitogen, endothelial regulator } \\
\text { and regulator of the collagen synthesis and secretion } \\
\text { of collagenase, stimulates angiogenesis and endothelial } \\
\text { chemotaxis, inhibits the proliferation of macrophages and } \\
\text { lymphocytes. }\end{array}$ & $\begin{array}{l}\text { Raines \& Ross (1982), } \\
\text { Martelossi Cebinelli et al. (2016), } \\
\text { Gatica et al. (2018) }\end{array}$ \\
\hline FGF & $\begin{array}{l}\text { Platelets, macrophages, } \\
\text { chondrocytes, } \\
\text { osteoblasts and } \\
\text { mesenchymal cells }\end{array}$ & $\begin{array}{l}\text { Mitogen for mesenchymal cells, chondrocytes and osteoblasts, } \\
\text { stimulates the growth and differentiation of chondrocytes } \\
\text { and osteoblasts. }\end{array}$ & $\begin{array}{l}\text { Raines \& Ross (1982), } \\
\text { Kharitonenkov \& Dimarchi (2017), } \\
\text { Ornitz \& Itoh (2015) }\end{array}$ \\
\hline PDGF a-b & $\begin{array}{l}\text { Platelets, macrophages/ } \\
\text { monocytes, endothelial } \\
\text { cells, osteoblasts and } \\
\text { smooth muscle cells }\end{array}$ & $\begin{array}{l}\text { Stimulates the chemotaxis and mitosis of fibroblasts, smooth } \\
\text { and glia muscle cells, regulates the secretion of collagenase } \\
\text { and collagen synthesis, mitogen for mesenchymal cells and } \\
\text { osteoblasts, stimulates the chemotaxy of macrophages and } \\
\text { neutrophils. }\end{array}$ & $\begin{array}{l}\text { Raines \& Ross (1982), } \\
\text { Hye Kim et al. (2015), } \\
\text { Heldin et al. (2018) }\end{array}$ \\
\hline $\begin{array}{l}\text { Epidermic } \\
\text { growth factor }\end{array}$ & $\begin{array}{l}\text { Platelets, macrophages/ } \\
\text { monocytes }\end{array}$ & $\begin{array}{l}\text { Stimulates mitosis of mesenchymal cells, regulates the } \\
\text { secretion of collagenase, stimulates chemotaxis and } \\
\text { angiogenesis of endothelial cells. }\end{array}$ & $\begin{array}{l}\text { Raines \& Ross (1982), } \\
\text { Wee \& Wang (2017), } \\
\text { Brown et al. (2016) }\end{array}$ \\
\hline VEGF & $\begin{array}{l}\text { Platelets, endothelial } \\
\text { cells }\end{array}$ & $\begin{array}{l}\text { Stimulates mitosis of endothelial cells, increases angiogenesis } \\
\text { and permeability of the vessel. }\end{array}$ & $\begin{array}{l}\text { Raines \& Ross (1982), } \\
\text { Simons et al. (2016), } \\
\text { Dehghani et al. (2018) }\end{array}$ \\
\hline IGF & $\begin{array}{l}\text { Platelets, macrophages, } \\
\text { osteoblasts, bone matrix } \\
\text { and mesenchymal cells }\end{array}$ & $\begin{array}{l}\text { Stimulates the differentiation and mitogenesis of } \\
\text { mesenchymal cells and of lining cells, stimulates osteoblasts } \\
\text { and the production of type I collagen, osteocalcin and alkaline } \\
\text { phosphatase. }\end{array}$ & $\begin{array}{l}\text { Raines \& Ross (1982), } \\
\text { Frater et al. (2018) }\end{array}$ \\
\hline
\end{tabular}


Table 2. Summary of the current literature regarding protocols for harvesting platelet rich plasma

\begin{tabular}{|c|c|c|c|c|c|c|}
\hline Reference & $\begin{array}{c}\text { Number of } \\
\text { centrifugations }\end{array}$ & $\begin{array}{c}\text { Gravitational } \\
\text { acceleration/ minutes }\end{array}$ & $\begin{array}{c}\text { Initial platelet } \\
\text { concentration } \\
\left(10^{3} / \mu \mathrm{L}\right)\end{array}$ & $\begin{array}{c}\text { Final platelet } \\
\text { concentration } \\
(\mathrm{PRP}) \\
\left(10^{3} / \mu \mathrm{L}\right)\end{array}$ & Resting time & $\begin{array}{l}\text { Result achieved } \\
\text { expressed as \% of } \\
\text { concentration }\end{array}$ \\
\hline Lee at al. (2018) & 2 & $\begin{array}{l}900 \mathrm{~g} \text { for } 15 \mathrm{~min} \\
200 \mathrm{~g} \text { for } 15 \mathrm{~min}\end{array}$ & 101.83 & 542.50 & None & $5.3 \%$ \\
\hline Giraldo et al. (2015) & 3 & $\begin{array}{l}120 \mathrm{~g} \text { for } 5 \mathrm{~min} \\
240 \mathrm{~g} \text { for } 5 \mathrm{~min} \\
3500 \mathrm{~g} \text { for } 8 \mathrm{~min}\end{array}$ & 143.8 & 390.6 & None & $2.7 \%$ \\
\hline Zuffova et al. (2013) & 1 & $1500 \mathrm{rpm}$ for $5 \mathrm{~min}$ & 87 & 466.5 & 1 hour & $5.3 \%$ \\
\hline Frye et al. (2016) & 2 & $\begin{array}{l}1200 \mathrm{~g} \text { for } 4 \mathrm{~min} \\
1,050 \mathrm{~g} \text { for } 9 \mathrm{~min}\end{array}$ & 214.70 & 1383.96 & $\begin{array}{l}30-120 \\
\min \end{array}$ & $6.4 \%$ \\
\hline Kwirant et al. (2019) & 2 & $\begin{array}{l}224 \mathrm{~g} \text { for } 10 \mathrm{~min} \\
440 \mathrm{~g} \text { for } 10 \mathrm{~min}\end{array}$ & 180.12 & 840.82 & None & $4.6 \%$ \\
\hline Miranda et al. (2018a) & 1 & $133 \mathrm{~g}$ for $8 \mathrm{~min}$ & 133.36 & 189.21 & $30 \mathrm{~min}$ & $1.4 \%$ \\
\hline Miranda et al. (2018b) & 2 & $\begin{array}{l}120 \mathrm{~g} \text { for } 10 \mathrm{~min} \\
240 \mathrm{~g} \text { for } 10 \mathrm{~min}\end{array}$ & 159.6 & 567.7 & 2 hours & $3.5 \%$ \\
\hline Bonilla-Gutiérrez et al. (2018) & 2 & $\begin{array}{l}120 \mathrm{~g} \text { for } 5 \mathrm{~min} \\
240 \mathrm{~g} \text { for } 5 \mathrm{~min}\end{array}$ & 130 & 370 & None & $2.8 \%$ \\
\hline Tian et al. (2019) & 2 & $\begin{array}{c}900 \mathrm{~g} \text { for } 5 \mathrm{~min} \\
1500 \mathrm{~g} \text { for } 15 \mathrm{~min}\end{array}$ & 219 & 1218 & None & $5.5 \%$ \\
\hline Xiong et al. (2018) & 1 & $180 \mathrm{~g}$ for $10 \mathrm{~min}$ & 216.4 & 525.7 & 1 hour & $2.4 \%$ \\
\hline
\end{tabular}

Platelet degranulation usually starts within one hour of blood collection and the clinical effects of this degranulation are controversial (Prado Vendruscolo et al. 2014). One way of assessing platelet degranulation is the measurement of P-selectin (Vestweber \& Blanks 1999) but other substances present in the $\alpha$-granules, such as VEGF, are likely candidates (Engels et al. 2015). The literature suggests that procedures with either single (Messora et al. 2009) or double (Carmona Ramírez \& Prades 2006, Vendramin et al. 2006) centrifugations, or consecutive centrifugations with increasing speeds can produce satisfactory PRP, bearing in mind that to qualify as "PRP" the end product must have at least a three-fold increase in platelets in relation to the original blood sample (Marx et al. 1998).

Platelet counts can be done via the direct manual method or using an automated protocol, although the International Council for Standardization of Haematology (ICSH) considers the manual method utilizing dilution, lysis and direct count with a hemocytometer as the gold standard (Tasker et al. 2001). Other authors argue that hemocytometer counting of platelets is heavily influenced by operator experience and the quality of the microscope (Olsen et al. 2004), and that in high throughput situations the manual count is unrealistic and should be replaced by the automated method, which provides a coefficient of variation below $10 \%$ in platelet counts between 40,000 and $500,000 / \mu \mathrm{L}$ (Veloso et al. 2011).

This study evaluated two different methods of PRP preparation to investigate if there was a significant difference in the concentration of platelets between the two, and compared platelet counts via the manual and the automated methods to investigate their association. In order to evaluate platelet degranulation during PRP preparation, VEGF was measured. The working hypotheses, based on the current status of knowledge, were that protocol preparation would influence platelet concentration in PRP, that manual and automated methods for platelet counting would provide similar results at different stages of the preparation protocols, and that one protocol might be more efficacious in preventing platelet degranulation.

\section{MATERIALS AND METHODS}

Ethics statement. This project was approved by the "Universidade Federal Fluminense" Ethics Committee (CEUA-UFF) under number 767.

Animals. Eight clinically healthy Quarter Horses, between five and seven years of age, including four males and four females, stabled at the same property under the same management conditions were recruited to participate in this research. Animals were kept in individual stalls during the night with daily access to paddocks. Feeding regimes included Pennisetum purpureum Schumach grass, alfalfa, commercial hard food twice daily, mineral salt, and fresh water ad libitum. Animals were not fasted prior to collection, although blood samples were taken early in the morning, prior to any food being provided. Inclusion criteria were: absence of hematological alterations, a normal clinical examination, no lameness or signs of active inflammation (localized or general), and not having been vaccinated against infectious diseases in the previous 60 days. After collection of blood samples, initial platelet count via the manual method had to be between 100.000 and $260.000 / \mu \mathrm{L}$ for the horse to remain in the study.

Study design. Blood collection was conducted by venipuncture of the external jugular vein utilizing vacuum tubes containing $3.2 \%$ sodium citrate ${ }^{\text {. }}$.

Twelve tubes per animal were collected to obtain an initial volume of blood of $60 \mathrm{~mL}$; tubes were separated in two groups of six tubes, one group per PRP protocol. The blood in the tubes was mixed by gentle inversion (10x) after which a $20 \mu \mathrm{L}$ aliquot was separated and diluted in $1.980 \mu \mathrm{L}$ of ammonium oxalate $2 \%$ for cell lysis. This aliquot was then submitted to the initial platelet count in the hemocytometer according to the method described in the

a Vacutainer, Becton Dickinson ${ }^{\circledR}$, Brazil. 


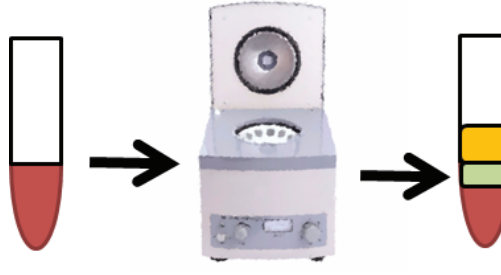

10 minutes at $120 \mathrm{~g}$

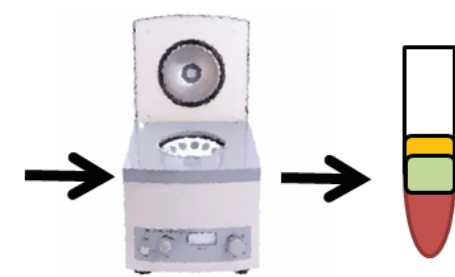

10 minutes at $240 \mathrm{~g}$

\section{2 hour rest \\ until \\ platelet}

counting

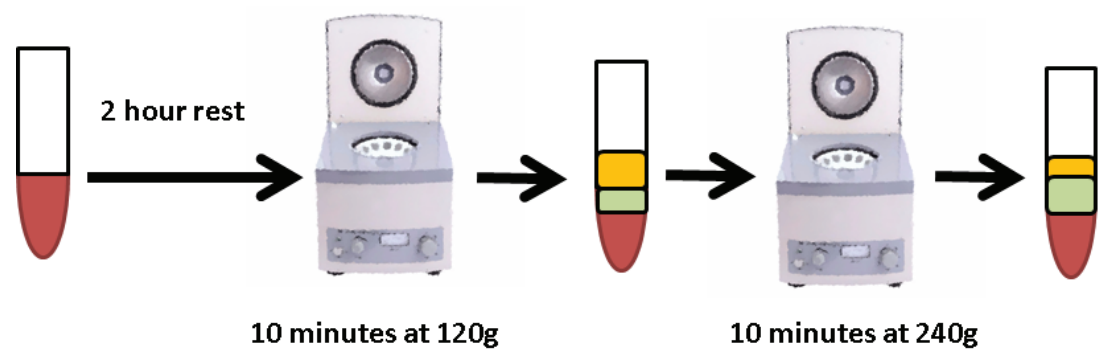

Fig.1. Diagrammatic view of the two protocols for PRP preparation with sample resting points highlighted, and supernatant aliquoting and aspiration indicated. The samples got separated into three layers by the first centrifugation. The first layer, comprising platelet poor plasma (represented as a yellow rectangle) got aliquoted for VEGF measurements. The second layer, including the buffy coat and platelet rich plasma (PRP, depicted as a green rectangle) was transferred to clean glass tubes and submitted to a second centrifugation. The third and final layer (red blood cells) was discarded. After the second centrifugation the process was repeated. The major difference between the protocols was the time point where samples were rested at room temperature for two hours. In Protocol I, shown at the top of the diagram, the sample was only rested as the very last step before platelet counting in PRP, while in the second protocol, shown at the bottom of the diagram, the sample was rested before the first centrifugation and that yielded better results.

literature (Jain 1993). Simultaneously another $100 \mu \mathrm{L}$ aliquot of the sample was processed in the automated equipment ${ }^{\mathrm{b}}$ for automated cell (including leukocytes) and platelet counts. Packed cell volume was done in a microtube centrifuge ${ }^{\mathrm{c}}$ and calculated hematocrit in the automated equipment calibrated for horses.

Protocols. PRP Protocol I consisted of immediate centrifugation of the six vacuum tubes in a bench top centrifuge ${ }^{\mathrm{d}}$ for 10 minutes at $120 \mathrm{~g}$ for initial plasma separation, after which the top 2/3 of the supernatant in each of the vacuum tubes was aspirated with a single channel pipette, aliquoted into microtubes, and frozen in liquid nitrogen for VEGF measurement. The final third of the supernatant and the buffy coat were aspirated as a pool into glass tubes and submitted to a second centrifugation for 10 minutes at $240 \mathrm{~g}$, after which the separation of the top $2 / 3$ and the final third of the supernatant was repeated as described above. The final third, considered to be the PRP, was subjected to a period of rest at room temperature for two hours. Average PRP yield volume was $2.5 \mathrm{ml}$. At the end of the rest period a platelet count on the PRP product was conducted manually and with the automated equipment, as described for the initial sample. Aliquots for VEGF measurement were also separated from the PRP final product.

PRP Protocol II consisted of an initial rest period of two hours at room temperature followed by the same centrifugations and

b Coulter T890 ${ }^{\circledR}$, Beckman Coulter, USA.

c Hematocrit, model.

d Centribio. supernatant separations as described above for Protocol I. The final PRP product, (average PRP yield volume obtained was $2.5 \mathrm{ml}$ ), was then submitted to platelet counts, both manually and by the automated method, as described above. Figure 1 details the methods, sample rest moments and aliquot separation times.

Concentration of VEGF. For VEGF concentration, Equine VEGF-A "Do-it-yourself" ELISA kit (Kingfisher, DIY0705E-003) was used according to manufacturer's instructions. Buffer dilution and concentrations were optimized in our lab and details are published elsewhere (Mello Costa 2017). Aliquots from three distinct points during PRP preparation were analyzed (after the first centrifugation, after the second centrifugation and at the completion of PRP preparation) and compared, as described in the PRP protocol description.

Statistics. ANOVA was utilized for investigating the influence of gender and age on the platelet counts obtained, to investigate the effect of protocol on VEGF concentration and to compare mean VEGF concentrations at the three distinct points. Significance was set at $95 \%(\mathrm{p} \leq 0.05)$.

Statistical analysis was conducted with specific software ${ }^{\mathrm{e}}$ and consisted of paired T-test analysis of initial and final counts for each of the protocols. Significance was set at $95 \%(p \leq 0.05)$.

Statistical evaluation of the automated method in relation to the manual method was conducted through dispersion and regression graphs. $\mathrm{R}$ values above 0.80 were considered to show a significant

$\overline{\text { e } \text { Minitab }^{\circledR} 17.3 .1,{ }^{\odot}}$ 2013, 2016 Minitab Inc., USA. 
correlation between the two methods. The association between the two methods was confirmed by plotting Bland Altman dispersion graphs.

Paired T-tests comparing the means of platelet counts from manual and automated processing methods (i.e. initial, intermediate and final platelet counts) was also conducted. Significance was set at $95 \%(\mathrm{p} \leq 0.05)$.

\section{RESULTS}

Results are presented as mean \pm standard deviation (SD) and test statistic results are followed by the $95 \%$ confidence interval, when pertinent.

There were no significant differences for any of the platelet counts, regardless of protocol or method, regarding animal gender or age.

Average initial platelet count by the manual method was $244.2 \times 103 / \mu \mathrm{L} \pm 21.3 \times 103 / \mu \mathrm{L}$ and $256.5 \times 103 / \mu \mathrm{L} \pm 37.8 \times 103 / \mu \mathrm{L}$ by the automated one. Final platelet counts for Protocol I with manual and automated methods were $463.0 \times 103 / \mu \mathrm{L} \pm 71.0 \times 103 / \mu \mathrm{L}$, and $513.2 \times 103 / \mu \mathrm{L} \pm 69.6 \times 103 / \mu \mathrm{L}$, respectively, while counts for Protocol II with manual and automated methods were $761.8 \times 103 / \mu \mathrm{L} \pm 41.9 \times 103 / \mu \mathrm{L}$ and $867 \times 103 / \mu \mathrm{L} \pm 219.3 \times 103 / \mu \mathrm{L}$ respectively. Protocol I offered a $202.3 \%$ increase in platelet count, while Protocol II offered a 307.5\% increase.

Final platelet counts were significantly higher than the initial counts for Protocols I and II, when the manual count was considered ( $\mathrm{p}<0.01 ; 166.9$ to 343.1 and $\mathrm{p}<0.01$; 478.9 to 555.4 respectively).

Similarly, final platelet counts were significantly higher for Protocols I and II, when the automated count was considered ( $p<0.01 ; 203.0$ to 346.5 and $p<0.01 ; 387.2$ to 765.6 respectively).

Protocol II offered a significantly higher final platelet count than Protocol I (manual count $\mathrm{p}<0.01 ; 179.0$ to 345.3; automated count $\mathrm{p}=0.02 ; 73.8$ to 525.3 ).

No significant differences in platelet counts were found between automated and manual methods for either protocol: p-values were 0.12 (initial manual compared to initial automated), 0.10 (final manual Protocol I versus final manual Protocol II), and 0.34 (final automated Protocol I versus final automated Protocol II).

Analysis of the association between the two methods (manual and automated) was conducted utilizing dispersion graphs according to Altman \& Bland (1983), as can be seen in Figure 2, which corroborates the good correlation between the two methods.

Visual inspection of platelets in blood smears did not show platelet activation as evidenced by the absence of pseudopods. As far as VEGF concentration, mean values and SD can be seen in Table 3. Mean VEGF concentration for Protocol I was $0.82 \mathrm{ng} / \mathrm{mL} \pm 0.04 \mathrm{ng} / \mathrm{mL} ; 0.79$ to 0.85 and $0.84 \mathrm{ng} / \mathrm{mL} \pm 0.04 \mathrm{ng} / \mathrm{mL} ; 0.80$ to 0.87 . Pooled SD was 0.04 .

There was no significant difference in VEGF concentrations among the three points for Protocol I ( $\mathrm{p}=0.57)$ nor Protocol II $(\mathrm{p}=0.06)$, and there was no difference in VEGF concentrations between Protocols I and II at any time ( $\mathrm{p}=0.42 ; \mathrm{f}=0.69)$.

Packed cell volume obtained from centrifugation and manual reading $(30.1 \% \pm 1.3)$ was not significantly different $(\mathrm{p}=0.26 ;-3.9$ to 1.6$)$ from the hematocrit by the automated method $(31.2 \% \pm 1.3)$.

The differences in final erythrocyte count $(\mathrm{p}=494 ;-0.56$ to 0.28$)$ and final leukocyte count ( $\mathrm{p}=0.084 ;-3.02$ to 40.02 ) between Protocol I and II were not significantly different. Both protocols

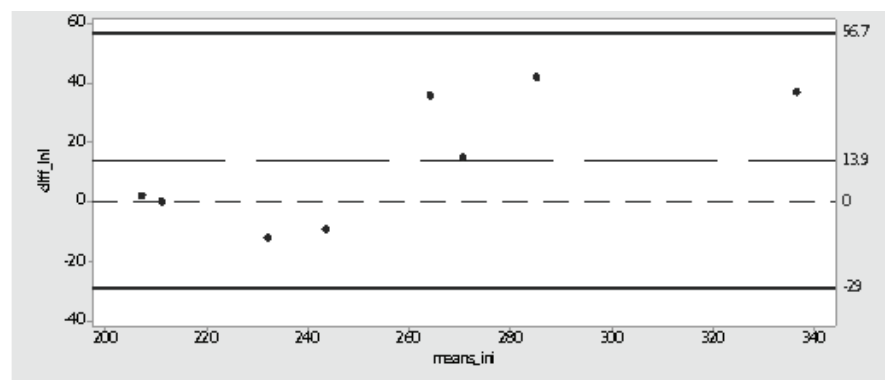

Fig.2. Altman \& Bland (1983) dispersion graph showing good association between the manual and automated platelet counts. diff_ini = difference between average platelet counts from manual and automated methods, means_ini = averages from reference method (manual).

Table 3. Mean VEGF concentrations and SD

\begin{tabular}{cccc}
\hline Measurement point & Protocol & $\begin{array}{c}\text { Mean VEGF } \\
\text { (ng/mL) }\end{array}$ & $\begin{array}{c}\text { SD } \\
(\mathrm{ng} / \mathrm{mL})\end{array}$ \\
\hline $\begin{array}{c}\text { After first } \\
\text { centrifugation }\end{array}$ & I & 0.82 & 0.04 \\
After second & II & 0.84 & 0.04 \\
centrifugation & I & 0.82 & 0.05 \\
PRP & II & 0.82 & 0.05 \\
& I & 0.92 & 0.27 \\
& II & 0.88 & 0.04
\end{tabular}

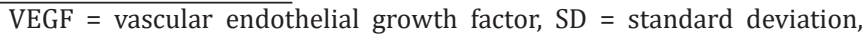
$\mathrm{PRP}=$ platelet rich plasma.

offered an increase in leukocytes $345.3 \%$ for Protocol I and $525.6 \%$ for Protocol II) and a decrease in erythrocyte numbers $(8.1 \%$ of initial erythrocytes left in Protocol I and $10.2 \%$ left in Protocol II).

\section{DISCUSSION}

Both protocols used in this study allowed concentration of platelets but only Protocol II (3.18x increase in platelet concentration) allowed for true production of PRP since final concentrations should be at least three times the initial ones (Marx 2004). Final platelet count with Protocol II was $761.8 \times 103 / \mu \mathrm{L} \pm 41.9 \times 103 / \mu \mathrm{L}$, which is higher than previous values reported in the literature by others (Carmona Ramírez \& Prades 2006, Vendruscolo etal. 2012). Similar research describing differences between protocols for PRP preparation present results in terms of fold-concentration obtained. In the case of this study a 3.18-fold increase was observed with Protocol II, while others report a 4-fold increase with their own protocols (DeRossi et al. 2009, Da Fontoura Pereira et al. 2013).

In this study, both protocols utilized two centrifugation cycles with increasing centrifugal forces, according to what has been described in the literature (DeRossi et al. 2009, Vendruscolo et al. 2012), but differing in relation to the moment of sample rest. It appears that allowing the sample to rest for two hours at room temperature at the start of the protocol, before centrifugation, is beneficial to obtaining a higher platelet count in the PRP harvested from the blood of Quarter Horses. The results corroborate the hypothesis that the protocol used influences the final PRP product. That, 
in return, might influence outcomes of possible therapeutic uses for the product.

One of the key aspects of the clinical outcome of PRP application is likely to rest in the concentration of active substances, rather than simply in the platelet counts. This work is part of a larger study which includes evaluation of active substances in the PRP and a review of its clinical application in a controlled trial.

In both protocols, a small amount of red blood cells was present in the PRP, with a smaller amount in Protocol I ( $0.51 / \mu \mathrm{L} \pm 0.79)$ in relation to Protocol II $(0.65 / \mu \mathrm{L} \pm 0.44)$ with a similar outcome for leukocyte counts. It is unknown whether a higher concentration of erythrocytes and leukocytes would affect the usage and outcomes of therapeutic PRP (Marx 2004, Carmona Ramírez \& Prades 2006, Vendramin et al. 2006), but previous investigations suggested that a small concentration of leukocytes would be desirable in order to maximize benefits arising from the increased platelet and GF concentrations in PRP (Pereira et al. 2013).

Both manual and automated methods provided similar counts for the parameters measured, in contrast with information provided previously stating that automated methods underestimate platelet values due to formation of aggregates (Tasker et al. 2001). This is likely because in both instances, manual and automated counts will tally clumped platelets as a single unit. In the present study, manual platelet count was conducted by a trained professional, reducing the possibility of operator error, as suggested by the literature (Olsen et al. 2004).

Therapeutic use of PRP in equine medicine, especially in dermatology, orthopaedics and inflammatory respiratory disorders has increased over the last few decades. Before studies investigating the effects of PRP use are properly conducted, an excellent working knowledge of the protocols for PRP preparation is required, including the use of a consistent method for aspiration and separation of PRP. This will ensure that the PRP is at optimal concentration and can provide the best possible outcome as far as platelet and GFs are concerned. Therapeutic effects can only be properly evaluated once the PRP protocols and techniques are standardized.

One issue that may arise during PRP preparation is the premature release of granules due to platelet activation. In the current study, PRP obtained was immediately used in a therapeutic protocol as part of ongoing research. VEGF concentration results indicate that platelet degranulation was avoided as evidenced by the lack of concentration differences among the points after each centrifugation and the PRP. Lack of platelet degranulation is reinforced by the observation of similar VEGF concentrations in Protocols I and II in the face of a significant larger platelet yield in Protocol II. It is important to emphasize that platelet activation and degranulation leading to release of $\alpha$-granule content might be desirable prior to therapeutic application in patients with inflammatory conditions, as is the case with PRP antimicrobial properties (Drago et al. 2013). It is also documented that PRP can be used with or without platelet activation (Amable et al. 2013).

The current research provides evidence of variation in the PRP final product depending on the protocol used for its preparation. The effects of the presence of erythrocytes and leukocytes in the PRP final product is yet to be clarified, and from this perspective, Protocol II in this research provided more blood cell contamination, although this difference was not statistically significant.

\section{CONCLUSIONS}

The results of this study indicate that the protocol for PRP preparation which includes resting the sample at room temperature for two hours, followed by two consecutive centrifugations at centrifugal forces of $120 \mathrm{~g}$ and $240 \mathrm{~g}$ for 10 minutes each, should be used.

The variation in VEGF was not significant, indicating preservation of $\alpha$-granules and lack of platelet degranulation during PRP preparation.

\section{REFERENCES}

Altman D.G. \& Bland J.M. 1983. Measurement in medicine: the analysis of method comparison studies. Statistician 32(3):307-317. <http://dx.doi. org/10.2307/2987937>

Amable P.R., Carias R.B., Teixeira M.V., Cruz Pacheco I., Corrêa do Amaral R.J., Granjeiro J.M. \& Borojevic R. 2013. Platelet-rich plasma preparation for regenerative medicine: optimization and quantification of cytokines and growth factors. Stem Cell Res. Ther. 4(3):67. <http://dx.doi.org/10.1186/ scrt218> <PMid:23759113>

Andrade M., Rodrigues G., Lima D., Faria L., Silva L., Souza R. \& Eurides D. 2016. Utilização de plasma rico em plaquetas de coelhos com poucos leucócitos e hemácias para a consolidação de ossos. Arq. Bras. Med. Vet. Zootec. 68(2):276-282. <http://dx.doi.org/10.1590/1678-4162-8304>

Anitua E., Andia I., Ardanza B., Nurden P. \& Nurden A.T. 2004. Autologous platelets as a source of proteins for healing and tissue regeneration. Thromb. Haemost. 91(1):4-15. <http://dx.doi.org/10.1160/TH03-070440> <PMid:14691563>

Bonilla-Gutiérrez A.F., Castillo-Franz C., López C., Álvarez M.E., Giraldo C.E. \& Carmona J.U. 2018. Equine suspensory ligament and tendon explants cultured with platelet-rich gel supernatants release different anti-inflammatory and anabolic mediators. Biomed. Pharmacother. 108:476-485.<http://dx.doi. org/10.1016/j.biopha.2018.09.065><PMid:30241051>

Bosch G., Van Schie H.T.M., De Groot M.W., Cadby J.A., Van De Lest C.H.A., Barneveld A. \& Van Weeren P.R. 2010. Effects of platelet-rich plasma on the quality of repair of mechanically induced core lesions in equine superficial digital flexor tendons: a placebo-controlled experimental study. J. Orthop. Res. 28(2):211-217. <PMid:19714688>

Bos-Mikich A., De Oliveira R. \& Frantz N. 2018. Platelet-rich plasma therapy and reproductive medicine. J. Assist. Reprod. Genet. 35(5):753-756. <http:// dx.doi.org/10.1007/s10815-018-1159-8><PMid:29564738>

Brossi P.M., Moreira J.J., Machado T.S. \& Baccarin R.Y. 2015. Platelet-rich plasma in orthopedic therapy: a comparative systematic review of clinical and experimental data in equine and human musculoskeletal lesions. BMC Vet. Res. 11(1):98. <http://dx.doi.org/10.1186/s12917-015-0403-z> <PMid:25896610>

Brown J., Su Y., Nellesen D., Shankar P. \& Mayo C. 2016. Management of epidermal growth factor receptor inhibitor-associated rash: a systematic review. J. Commun. Support. Oncol. 14(1):21-28. <http://dx.doi.org/10.12788/ jcso.0193><PMid:26870839>

Carmona Ramírez J.U. \& Prades M. 2006. Use of autologous platelet concentrates for the treatment of musculoskeletal injuries in the horse. Doctoral Dissertation, Universitat Autònoma de Barcelona, Bellaterra. 100p.

Chahla J., Cinque M.E., Piuzzi N.S., Mannava S., Geeslin A.G., Murray I.R. Dornan G.J., Muschler G.F. \& LaPrade R.F. 2017. A call for standardization in platelet-rich plasma preparation protocols and composition reporting: a systematic review of the clinical orthopaedic literature. J. Bone Joint Surg. 99(20):1769-1779. <http://dx.doi.org/10.2106/JBJS.16.01374> <PMid:29040132> 
Comar S.R., Danchura H.S. \& Silva P.H. 2009. Contagem de plaquetas: avaliação de metodologias manuais e aplicação na rotina laboratorial. Revta Bras. Hematol Hemoter. 31(6):431-436. <http://dx.doi.org/10.1590/S151684842009005000087>

Dehghani S., Nosrati R., Yousefi M., Nezami A., Soltani F., Taghdisi S.M., Abnous K., Alibolandi M. \& Ramezani M. 2018. Aptamer-based biosensors and nanosensors for the detection of vascular endothelial growth factor (VEGF): a review. Biosens. Bioelectron. 110:23-37. <http://dx.doi.org/10.1016/j. bios.2018.03.037><PMid:29579646>

DeRossi R., Coelho A.C.A.D.O., Mello G.S.D., Frazílio F.O., Leal C.R.B., Facco G.G. \& Brum K.B. 2009. Effects of platelet-rich plasma gel on skin healing in surgical wound in horses. Acta Cir. Bras. 24(4):276-281. <http://dx.doi. org/10.1590/S0102-86502009000400006><PMid:19705027>

Drago L., Bortolin M., Vassena C., Taschieri S. \& Del Fabbro M. 2013. Antimicrobial activity of pure platelet-rich plasma against microorganisms isolated from oral cavity. BMC Microbiol. 13(1):47.<http://dx.doi.org/10.1186/14712180-13-47><PMid:23442413>

Engels E.A., Jennings L., Kemp T.J., Chaturvedi A.K., Pinto L.A., Pfeiffer R.M., Trotter J.F., Acker M., Onaca N. \& Klintmalm G.B. 2015. Circulating TGF-B1 and VEGF and risk of cancer among liver transplant recipients. Cancer Med. 4(8):1252-1257. <http://dx.doi.org/10.1002/cam4.455><PMid:25919050>

Frater J., Lie D., Bartlett P. \& McGrath J.J. 2018. Insulin-like growth factor 1 (IGF-1) as a marker of cognitive decline in normal ageing: a review. Ageing Res. Rev. 42:14-27.<http://dx.doi.org/10.1016/j.arr.2017.12.002> <PMid:29233786>

Frye C.W., Enders A., Brooks M.B., Struble A.M. \& Wakshlag J.J. 2016. Assessment of canine autologous platelet-rich plasma produced with a commercial centrifugation and platelet recovery kit. Vet. Comp. Orthop. Traumatol. 29(1):14-19. <http://dx.doi.org/10.3415/VCOT-15-03-0046> $<$ PMid:26603823>

Gatica S., Cabello-Verrugio C. \& Simon F. 2018. Transforming growth factorbeta family: advances in vascular function and signaling. Curr. Protein Pept. Sci. 19(12):1164-1171. <http://dx.doi.org/10.2174/138920371966617 1128114730><PMid:29189145>

Giraldo C.E., Álvarez M.E. \& Carmona J.U. 2015. Effects of sodium citrate and acid citrate dextrose solutions on cell counts and growth factor release from equine pure-platelet rich plasma and pure-platelet rich gel. BMC Vet. Res. 11(1):60. <http://dx.doi.org/10.1186/s12917-015-0370-4> $<$ PMid:25889052>

Heldin C.H., Lennartsson J. \& Westermark B. 2018. Involvement of plateletderived growth factor ligands and receptors in tumorigenesis. J. Intern. Med. 283(1):16-44. <http://dx.doi.org/10.1111/joim.12690><PMid:28940884>

Hye Kim J., Gyu Park S., Kim W.K., Song S.U. \& Sung J.H. 2015. Functional regulation of adipose-derived stem cells by PDGF-D. Stem Cells 33(2):542556. <http://dx.doi.org/10.1002/stem.1865><PMid:25332166>

Jain N.C. 1993. Essentials of Veterinary Hematology. Lea and Febiger, Philadelphia. $417 \mathrm{p}$.

Kharitonenkov A. \& DiMarchi R. 2017. Fibroblast growth factor 21 night watch: advances and uncertainties in the field. J. Intern. Med. 281(3):233-246. <http://dx.doi.org/10.1111/joim.12580><PMid:27878865>

Kwirant L.A.D.A., De La Corte F.D., Cantarelli C., Cargnelutti J.F., Martins M., Cabral M.W., Maciel N. \& Rubin M.I.B 2019. Cooling and cryopreservation of equine platelet-rich plasma with dimethyl sulfoxide and trehalose. J. Equine Vet. Sci. 72:112-116.<http://dx.doi.org/10.1016/j.jevs.2018.10.009> <PMid:30929774>

Laudy A.B., Bakker E.W., Rekers M. \& Moen M.H. 2015. Efficacy of plateletrich plasma injections in osteoarthritis of the knee: a systematic review and meta-analysis. Brit. J. Sports Med. 49(10):657-672. <http://dx.doi. org/10.1136/bjsports-2014-094036><PMid:25416198>
Lee E.B., Kim J.W. \& Seo J.P. 2018. Comparison of the methods for platelet rich plasma preparation in horses. J. Anim. Sci. Technol. 60(1):20.<http:// dx.doi.org/10.1186/s40781-018-0178-4><PMid:30147942>

Maciel F.B., DeRossi R., Módolo T.J., Pagliosa R.C., Leal C.R. \& Delben A.A. 2012. Scanning electron microscopy and microbiological evaluation of equine burn wound repair after platelet-rich plasma gel treatment. Burns 38(7):1058-1065. <http://dx.doi.org/10.1016/j.burns.2012.02.029> $<$ PMid:22683140>

Marcazzan S., Weinstein R.L. \& Del Fabbro M. 2018. Efficacy of platelets in bone healing: a systematic review on animal studies. Platelets 29(4):326-337. <http://dx.doi.org/10.1080/09537104.2017.1327652><PMid:28643535>

Martelossi Cebinelli G.C., Paiva Trugilo K., Badaró Garcia S. \& Brajão de Oliveira K 2016. TGF- $\beta 1$ functional polymorphisms: a review. Eur. Cytokine Netw. 27(4):81-89. <http://dx.doi.org/10.1684/ecn.2016.0382><PMid:28396298>

Marx R.E. 2004. Platelet-rich plasma: evidence to support its use. J. Oral Maxillofac. Surg. 62(4):489-496. <http://dx.doi.org/10.1016/j. joms.2003.12.003><PMid:15085519>

Marx R.E., Carlson E.R., Eichstaedt R.M., Schimmele S.R., Strauss J.E. \& Georgeff K.R. 1998. Platelet-rich plasma: growth factor enhancement for bone grafts. Oral Surg. Oral Med. Oral Pathol. Oral Radiol. Endod. 85(6):638-646. <http://dx.doi.org/10.1016/S1079-2104(98)90029-4><PMid:9638695>

Mello Costa M.F. 2017. Investigação de substâncias endógenas e expressão gênica de biomarcadores de enfermidades respiratórias em equinos. Relatório de Pesquisa, Fundação de Amparo à Pesquisa do Estado do Rio de Janeiro (FAPERJ), Rio de Janeiro, p.20.

Messora M.R., Nagata M.J.H., Melo L.G.N.D., Furlaneto F.A.C., Deliberador T.M., Garcia V.G. \& Bosco A.F. 2009. Análise de um protocolo de única centrifugação para o preparo do plasma rico em plaquetas (PRP): estudo em coelhos. RSBO 6(2):135-141.

Miranda A.L.S., Soto-Blanco B., Lopes P.R., Victor R.M. \& Palhares M.S. 2018a. Influence of anticoagulants on platelet and leukocyte concentration from platelet-rich plasma derived from blood of horses and mules. J. Equine Vet. Sci. 63:46-50. <http://dx.doi.org/10.1016/j.jevs.2018.01.003>

Miranda S., Costa M.F.D.M., Senna J.J., Frapoint J.C., De Alencar N.X. \& Lessa D.A.B. 2018b. Effects of breed/species and gender on platelet concentration in autologous platelet rich plasma. Acta Vet. Brno 68(4):474-483. <http:// dx.doi.org/10.2478/acve-2018-0038>

Ng Y.-S., Krilleke D. \& Shima D.T. 2006. VEGF function in vascular pathogenesis. Experim. Cell Res. 312(5):527-537. <http://dx.doi.org/10.1016/j. yexcr.2005.11.008> <PMid:16330026>

Olsen L.H., Kristensen A.T., Qvortrup K. \& Pedersen H.D. 2004. Comparison of manual and automated methods for determining platelet counts in dogs with macrothrombocytopenia. J. Vet. Diagn. Invest. 16(2):167-170. <http://dx.doi.org/10.1177/104063870401600215><PMid:15053372>

Ornitz D.M. \& Itoh N. 2015. The fibroblast growth factor signaling pathway. WIREs Develop. Biol. 4(3):215-266. <PMid:25772309>

Pereira R.C.F., Zacarias G.V.F., Cantarelli C., Corrêa M.M.B., Silva G.B., Barbosa A.L.T., Brass K.E. \& Côrte F.D.D.L. 2013. Avaliação de sete protocolos para obtenção de plasma rico em plaquetas na espécie equina. Ciência Rural 43(6):1122-1127.<http://dx.doi.org/10.1590/S0103-84782013005000052>

Prado Vendruscolo C., Garcia Alves A.L., Monaco Brossi P. \& Arantes Baccarin R.Y. 2014. Uso do soro autólogo condicionado e do plasma rico em plaquetas na terapia ortopédica de equinos. Semina, Ciênc. Agrárias 35(5):2607-2624.

Ross R., Raines E.W. \& Bowen-Pope D.F. 1986. The biology of platelet-derived growth factor. Cell 46(2):155-169. <http://dx.doi.org/10.1016/00928674(86)90733-6><PMid:3013421>

Raines E.W. \& Ross R. 1982. Platelet-derived growth factor. I. High yield purification and evidence for multiple forms. J. Biol. Chem. 257(9):51545160. <PMid:7068680> 
Sheth U., Simunovic N., Klein G., Fu F., Einhorn T.A., Schemitsch E., Ayeni O.R. \& Bhandari M. 2012. Efficacy of autologous platelet-rich plasma use for orthopaedic indications: a meta-analysis. J. Bone Joint Surg. 94(4):298-307. <http://dx.doi.org/10.2106/JBJS.K.00154> <PMid:22241606>

Simons M., Gordon E. \& Claesson-Welsh L. 2016. Mechanisms and regulation of endothelial VEGF receptor signalling. Nat. Rev. Mol. Cell Biol. 17(10):611625. <http://dx.doi.org/10.1038/nrm.2016.87> <PMid:27461391>

Tambella A.M., Attili A.R., Dupré G., Cantalamessa A., Martin S., Cuteri V., Marcazzan S. \& Del Fabbro M. 2018. Platelet-rich plasma to treat experimentally-induced skin wounds in animals: a systematic review and meta-analysis. PloS One 13(1):e0191093. <http://dx.doi.org/10.1371/ journal.pone.0191093><PMid:29324848>

Tasker S., Cripps P. \& Mackin A. 2001. Evaluation of methods of platelet counting in the cat. J. Small Anim. Pract. 42(7):326-332. <http://dx.doi. org/10.1111/j.1748-5827.2001.tb02467.x><PMid:11480897>

Tian J., Cheng L.H.H., Cui X., Lei X.X., Tang J.B. \& Cheng B. 2019. Application of standardized platelet-rich plasma in elderly patients with complex wounds. Wound Repair Regen. 27(3):268-276. <http://dx.doi.org/10.1111/ wrr.12702><PMid:30693614>

Veloso W.A., Alencar S.M.F. \& Cardozo S.V. 2011. Avaliação dos critérios adotados no interfaceamento dos resultados dos hemogramas automatizados. Revta Acad. Saúde Amb. 6(1):4-10.
Vendramin F.S., Franco D., Nogueira C.M., Pereira M.S. \& Franco T.R. 2006. Plasma rico em plaquetas e fatores de crescimento: técnica de preparo e utilização em cirurgia plástica. Revta Col. Bras. Cir. 33(1):24-28. <http:// dx.doi.org/10.1590/S0100-69912006000100007>

Vendruscolo C.P., Carvalho A.M., Moraes L.F., Maia L., Queiroz D.L., Watanabe M.J., Yamada A.L.M. \& Alves A.L.G. 2012. Avaliação da eficácia de diferentes protocolos de preparo do plasma rico em plaquetas para uso em medicina equina. Pesq. Vet. Bras. 32(2):106-110. <http://dx.doi.org/10.1590/ S0100-736X2012000200002>

Vestweber D. \& Blanks J.E. 1999. Mechanisms that regulate the function of the selectins and their ligands. Physiol. Rev. 79(1):181-213.<http://dx.doi. org/10.1152/physrev.1999.79.1.181><PMid:9922371>

Wee P. \& Wang Z. 2017. Epidermal growth factor receptor cell proliferation signaling pathways. Cancers 9(5):52. <PMid:28513565>

Xiong G., Lingampalli N., Koltsov J.C., Leung L.L., Bhutani N., Robinson W.H. \& Chu C.R. 2018. Men and women differ in the biochemical composition of platelet-rich plasma. Am. J. Sports Med. 46(2):409-419. <http://dx.doi. org/10.1177/0363546517740845> <PMid:29211968>

Zuffova K., Krisova S. \& Zert Z. 2013. Platelet rich plasma treatment of superficial digital flexor tendon lesions in racing Thoroughbreds. Vet. Med. 58(4):230-239. <http://dx.doi.org/10.17221/6761-VETMED> 